\title{
Thermal Impacts of Vertical Greenery Systems
}

\author{
Tabassom Safikhani ${ }^{1}$, Aminatuzuhariah Megat Abdullah ${ }^{2}$, Dilshan Remaz Ossen ${ }^{3}$, Mohammad Baharvand $^{4}$, \\ ${ }^{1-4}$ Universiti Teknologi Malaysia
}

\begin{abstract}
Using vertical greenery systems to reduce heat transmission is becoming more common in modern architecture. Vertical greenery systems are divided into two main categories; green facades and living walls. This study aims to examine the thermal performance of vertical greenery systems in hot and humid climates. An experimental procedure was used to measure indoor temperature and humidity. These parameters were also measured for the gap between the vertical greenery systems and wall surfaces. Three boxes were used as small-scale rooms. Two boxes were provided with either a living wall or a green facade and one box did not have any greenery (benchmark). Blue Trumpet Vine was used in the vertical greenery systems. The data were recorded over the course of three sunny days in April 2013. An analyses of the results showed that the living wall and green facade reduced indoor temperature up to $4.0{ }^{\circ} \mathrm{C}$ and $3.0^{\circ} \mathrm{C}$, respectively. The living wall and green facade also reduced cavity temperatures by $8.0^{\circ} \mathrm{C}$ and $6.5^{\circ} \mathrm{C}$, respectively.
\end{abstract}

Keywords - Green facade, Living wall, Temperature, Vertical greenery system.

\section{INTRODUCTION}

Greenery systems as a part of a building are a response to growth and urbanization that create large expanses of concrete and other impermeable surfaces such as buildings, roads, and pavement [1]. There are different kinds of greenery systems in cities such as public green areas, green roofs, and vertical greenery systems [2].

Vertical greenery systems [3], [4], vertical landscaping [2], and vertical gardening refer to techniques used to grow plants on vertical surfaces [5], [6]. These systems can be natural or manmade and they can be installed inside buildings as bio statues, interior walls, or partitions. Outside, vertical greenery systems take the form of fences, surrounding balconies, or building covers [7]. Using vertical greenery systems dates back to ancient times when the Hanging Gardens of Babylon were an early example [1]. The Hanging Gardens of Babylon were one of the original Seven Wonders of the World and they were built by the Chaldean King, Nebuchadnezzar, around $600 \mathrm{BC}$. More recently, the methods and purposes of vertical landscaping have been updated using modern techniques and technologies.

Vertical greenery systems provide numerous economic, environmental, and social benefits for urban dwellers as well as benefiting the structure of the building [8]. They clean the air by absorbing dust and reducing air pollution [1], [9] and they provide fresh air by consuming carbon dioxide and restoring oxygen [10]. At the same time, they provide shade and their evapotranspiration capabilities control the temperature of the building [4], [11]. Consequently, greenery systems reduce urban heat islands and global warming [12] while providing pleasant and aesthetic views [1], [13].
Vertical landscaping is composed of the plants, growing media, and systems [7]. Plants are significant, and they should be selected based on the type of the system used, environment factors, expected degree of maintenance, and budget. Growing media is where the roots of the plants find their nutrition. It can be regular soil, lightweight soil, felt, or foam [7]. Regular soil is produced by decaying plants and animals, and it provides nutrients for plants growth. Lightweight soil is a balanced soil, made of compost, peat moss, and minerals. Felt is a soil substrate that provides a platform for plant growth. Plants are potted into felt pockets and nutrients are provided through watering. Foam is a light and stable substrate that transfers nutrients from the water to the plants [7]. The type of growing media determines the type of system that can take the form of a green facade or living wall.

All vertical greenery systems are divided into green facades and living walls [8], [14], [15]. In vertical greenery systems, the growing media is placed on the ground and the plants grow vertically to cover the wall. It is also possible to place the growing media vertically on the surface of the wall. The first configuration is called a green facade and the second configuration is called a living wall or vertical garden [8], [14], [15]. Both of these vertical greenery systems can reduce air [11], ambient, and surface temperatures as well as heat flux [16]. Fig. 1 illustrates both greenery systems in front of a sample box.

Green facades are inexpensive and they do not require much experience or money. They were commonly used in traditional architecture, especially because of their aesthetic impact, but also for heat reduction effects [17].

The efficiency of green facades is directly dependent on the shape and density of leaves [4]. Small leaves can grow between larger leaves, fill holes, and provide dense foliage for shading. Moreover, air can flow through the leaves and ventilate the whole system. In dry Mediterranean continental climates, green facades not only reduce heat, but they also decrease the temperature of the air cavity located between the green facade and the wall surface [18]. An experiment in Thailand revealed the effective integration of natural ventilation and green facade on temperature reduction in hot and humid climates [19].

Growing enough plants to cover the entire surface of a building takes time. Additionally, in a green facade, if one plant becomes damaged or dies, the entire facade may need to be replaced. Other kinds of vertical greenery systems, such as living walls or vertical gardens, provide a solution. These systems use modular pre-vegetated panels that are installed on the wall structure or on independent vertical structures in front of the main facade. There are different modules for living 
walls such as G-sky, Green Wall Containers, Woolly Pockets, VertiGarden, Philly Green Wall, and Fytowall [7]. G-sky and Green Wall Containers are produced in the United States and Canada for non-residential projects. Woolly pocket systems are popular and consist of plants stacked on vertical surfaces in pouches. A British company produces VertiGardens that are composed of plastic panels in zinc-plated steel frames. Philly Green Walls are produced in the United States, and they are constructed of recyclable aluminum and stainless steel. Fytowalls are cells used in commercial and residential buildings and produced by an Australian company [7]. Growing plants in each module of a living wall to cover an entire surface needs less time in comparison with green facades and if one plant is damaged or dies, it is possible to change only that module instead of the entire façade.

Based on the materials used in a living wall, they can provide extensive shading to the wall and this effect will reduce the temperature of the building while limiting airflow [20]. Blocked air acts as insulation for internal spaces and leads to temperature increases [20]. The effect on temperature between direct green facades, indirect green facades and living walls was studied by Dutch researchers [14]. They found that living walls $4 \mathrm{~cm}$ from the building blocked the air behind it [14]. This property is preferred in colder climates to protect buildings against cold, outside conditions. In a study conducted in Singapore, the heat reduction capabilities of eight different types of vertical greenery systems were compared [4]. This study examined the vertical greenery system, and the plants, substrate materials, and growing media used by each system. All vertical greeneries studied reduced the temperature behind the walls, but wider plant coverage and denser plant leaves provided greater temperature reduction. Living walls with modular panels achieved better levels of temperature reduction in comparison with other vertical greenery systems [4]. The study was based on surface and ambient temperatures, but inside temperature and humidity were not considered.

Both shading and airflow are essential to reducing inside, ambient, and surface temperatures. Living walls have strong shading effects and the success of green facades depends on the ventilation effect provided by the foliage. Unfortunately, there are limited studies that compare the thermal performance of living walls and green facades in hot and humid climates like Malaysia. Accordingly, this study attempted to discover the different thermal effects of dense and full cover leaves for green facades with modular living walls covered with felt substrate in Malaysia in order to understand their effect on indoor temperatures and humidity. These effects were also studied for the air cavities between the vertical greeneries and the buildings.
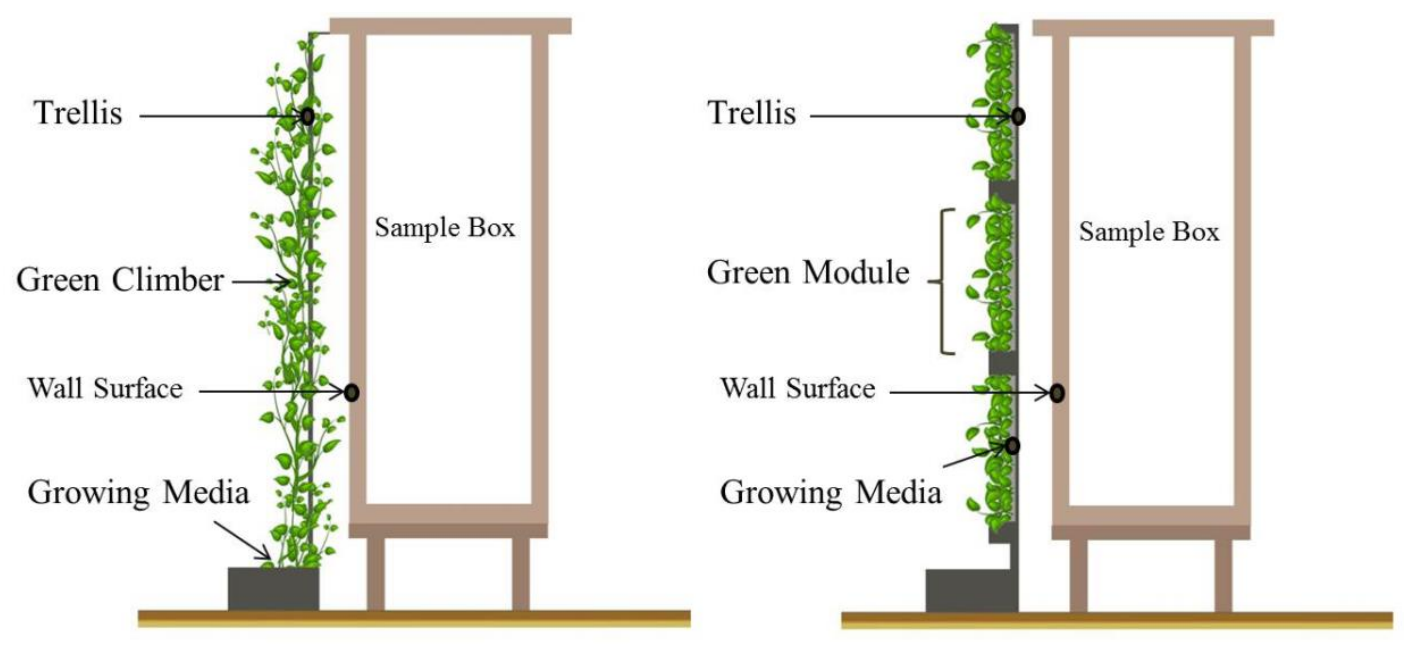

Fig. 1. Green facade (left) and living wall (right).

\section{Methodology}

\section{A. Trellises}

In this study, a small-scale experiment was conducted that attempted to create a situation that was the same as the real world conditions experienced by greenery systems. To begin the test, two identical trellises were needed. The trellises consisted of a timber framework with mesh entwined inside the timber frame. The trellis dimensions were $160 \mathrm{~cm} \cdot 100 \mathrm{~cm}$ and provided $1.6 \mathrm{~m}^{2}$ of surface area for plants to grow. One timber trellis was used as a green facade and the other trellis was used as a living wall. Blue Trumpet Vine (Thunbergia grandiflora) was used on both trellises as this plant can climb walls and it is well suitable to tropical climates. The number and quality of potted plants in both systems were similar and the thicknesses of the plants on trellises were about $20 \mathrm{~cm}$. The green facade was installed in January 7, 2013, and the plants grew to cover the whole trellis (Fig. 2 (a)).

The roots of the plants in the green facade were planted in a box filled with soil to simulate the ground. The plants grew quickly during the first month and covered the entire trellis surface. After that, the leaves furled around the trellis mesh, filled the area, and provided dense foliage for the green facade. Fig. 2 (a) shows the trellis used for the green facade as well as the growth of the plants. The other trellis was used as a living wall by covering it with a layer of felt as a substrate. It 
(a)
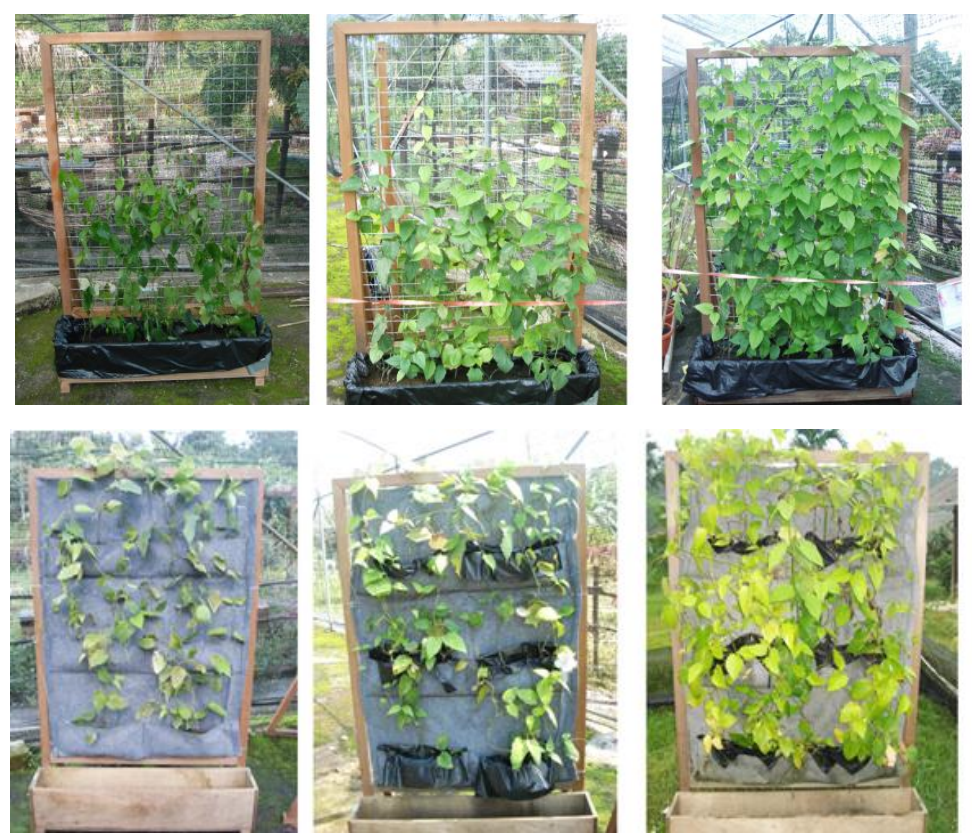

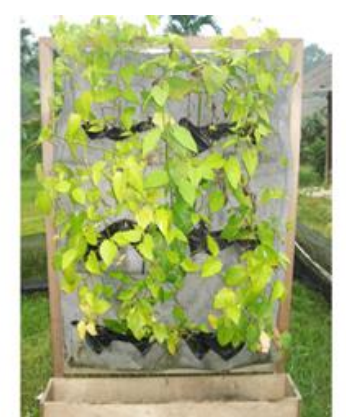

(b)

Fig. 2. Green facade trellis and plant growth (a), and living wall trellis and plant growth (b).

contained six pockets to hold the plants, and the system was installed March 3, 2013 (Fig. 2 (b)). Growing plants in different parts of the mesh lead to a completely green surface in a short period of time. Fig. 2 (b) displays the living wall trellis and growth of the plants.

\section{B. Test Box Samples and Instruments}

Three identical test boxes were needed for this experiment to act as small-scale test rooms. The outside dimensions of the boxes were $60 \mathrm{~cm} \cdot 60 \mathrm{~cm} \cdot 160 \mathrm{~cm}$. The boxes stood on pillars that held the boxes $20 \mathrm{~cm}$ above the ground. The test boxes were made from $1.2 \mathrm{~cm}$ thick plywood. Each box had two openings. The size of the upper opening was $40 \mathrm{~cm} \cdot 20 \mathrm{~cm}$ and the lower opening was $40 \mathrm{~cm} \cdot 10 \mathrm{~cm}$. In the first part of the test, both openings were closed and the effects of the vertical greenery systems were considered. In the second part of the test, both openings were opened fully to investigate the thermal performance of greenery systems with and without natural ventilation. The roofs of the boxes had $10 \mathrm{~cm}$ side tent. The distance of green systems from the walls of the test boxes were $15 \mathrm{~cm}$. In other words, the vertical green systems were 5 $\mathrm{cm}$ away from the tents. A west orientation was selected for installing the vertical greenery systems to examine its effects under the hot afternoon sun.

The tests were conducted on the farm of the Universiti Teknologi Malaysia (UTM), Johor Skudai campus in Malaysia. The site was an open area without any trees or buildings.

Six RTR data loggers and three sets of four channel Hobo U12 were used for the experiment. The RTR data loggers were hung in polystyrene pots covered with aluminum to protect them against direct solar radiation. They were used to measure inside and outside air temperature and humidity. The measurement points for air temperature and air humidity were located in the middle of the test boxes and in the middle of the cavity (Fig. 3).

The Hobos were used to measure surface temperature. The first channel of each Hobo was used to measure inside surface temperatures, and the fourth channel was used to measure outside surface temperatures. For each test room one hobo and two wires were needed (Fig. 3). The hobos were installed at the centre the internal and external surfaces to record surface temperatures. Fig. 3 shows the location of measuring points on the surfaces and in the centre of the test boxes.

The data was collected over the course of three days beginning on April 14, 2013 at 7:00 pm and continuing until April 17, 2013 at 7:00 pm. These three days were cloudless and sunny. To achieve accurate results, data was collected every 5 minutes. The analysis was based on hourly average data over a 24 hours period that started at midnight and continued until midnight on the following day.

\section{DISCUSSION AND ANALYSIS}

Installing vertical greenery systems in front of wall surfaces created a cavity between the vertical greenery systems and the wall surfaces. The cavity created a small microclimate with specific thermal conditions. Cavity air temperature, cavity surface temperature, and cavity humidity changes were based on outside weather conditions and the performance of the vertical greenery systems. These microclimates directly affected indoor conditions. Roof and surrounding walls protected indoor conditions against climatic components. The heat of the sun is absorbed by the outside surfaces of a building and is transferred to inside surfaces, thus affecting indoor air conditions. This process increases indoor temperatures. The thermal comfort of the occupants of the building is strongly affected by indoor conditions. During this 


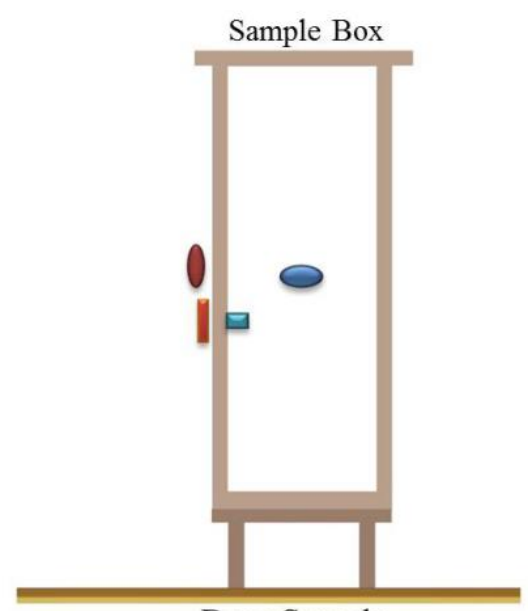

Base Sample

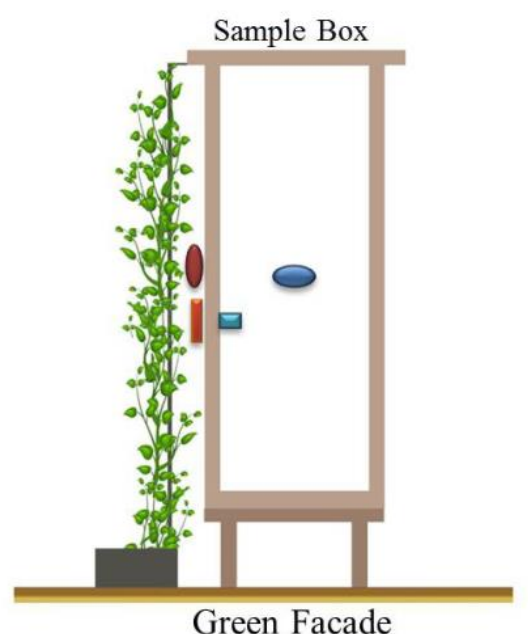

Green Facade

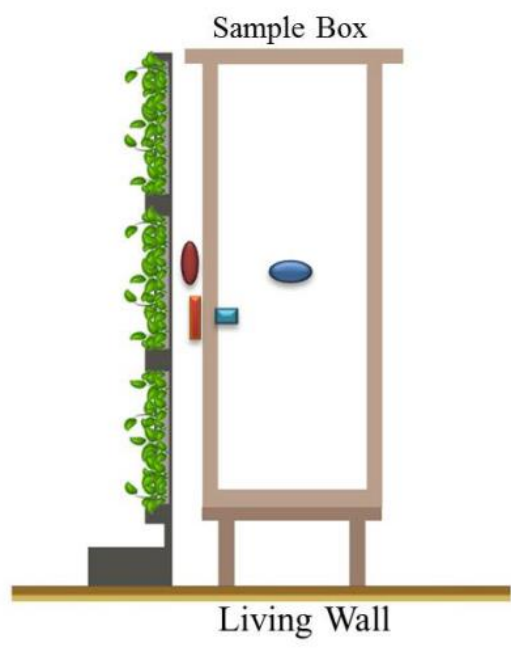

Living Wall

\section{Outside Air Temperature and Humidity/ |Outside Surface Temperature Inside Air Temperature and Humidity/ $\bullet$ Inside Surface Temperature}

Fig. 3. Location of data loggers and hobos for bare facade (left), green facade (middle) and living wall (right).

study, inside conditions were not in the thermal comfort range because the goal of this study was to discover the effects of green facades and living walls on indoor temperature reductions and provide higher levels of thermal comfort.

\section{A. Thermal Effects of Green Facades and Living Walls}

Fig. 4 shows the temperature and humidity for the test boxes with the green facade, living wall, and bare facade. The test box without any greenery was used as base model and benchmark for comparison purposes.

The results showed that both the green facade and living wall reduced the temperatures of inside the test boxes and temperatures of cavity especially in the afternoon. During the morning, direct solar radiation fell on the east part of the test boxes. Plants on the west side reduced temperatures using natural evapotranspiration and cooling effects. At that time, plants situation and the substrate properties reduce temperature better than the green facade. Moreover, the cavity temperature and the inside temperature behind the living wall were less than the inside temperature behind the green facade. In the afternoon when outside temperatures are at their highest, vertical greenery systems have a significant effect on temperature reduction. During the afternoon when direct solar radiation hits the plants on the west side, cooling effect and the shade provided by the vertical greenery systems effectively reduce temperature.

The substrate surface of the living wall had a significant effect on temperature reduction. At the hottest time of the day, the living wall and green facade reduced cavity temperatures by $8.0^{\circ} \mathrm{C}$ and $6.5^{\circ} \mathrm{C}$, respectively. Inside temperatures were reduced by $4.0^{\circ} \mathrm{C}$ and $3.0^{\circ} \mathrm{C}$ for the living wall and green facade, respectively.

After sunset and during the night, all test boxes had approximately the same cavity and inside temperatures, but the inside temperature behind green facade was about $0.5^{\circ} \mathrm{C}$ higher. This was because the plants and foliage of the green facade were directly connected to the wall surface, acting as bumper and did not allow warm inside air to ventilate via the wall surface.

Fig. 4 shows that, although installing vertical greenery systems have a positive effect on indoor temperatures in hot and humid climates, they have a negative effect on humidity control. Both green facade and living wall increased humidity, but the process was different in the cavity compared to inside the test boxes. The green facade increased cavity humidity more than the living wall because the leaves and foliage in the green facade interfere with evaporation in the cavity increase humidity. The humidity inside the test box behind the living wall was greater than the humidity for test box behind the green facade. This was due to the substrate cover that acted as a blanket and kept humidity inside the test box and did not allow ventilation.

Humidity is one of the important parameters in thermal comfort. When installing vertical greenery systems to reduce temperature, attention must be given to ventilation and humidity control. 

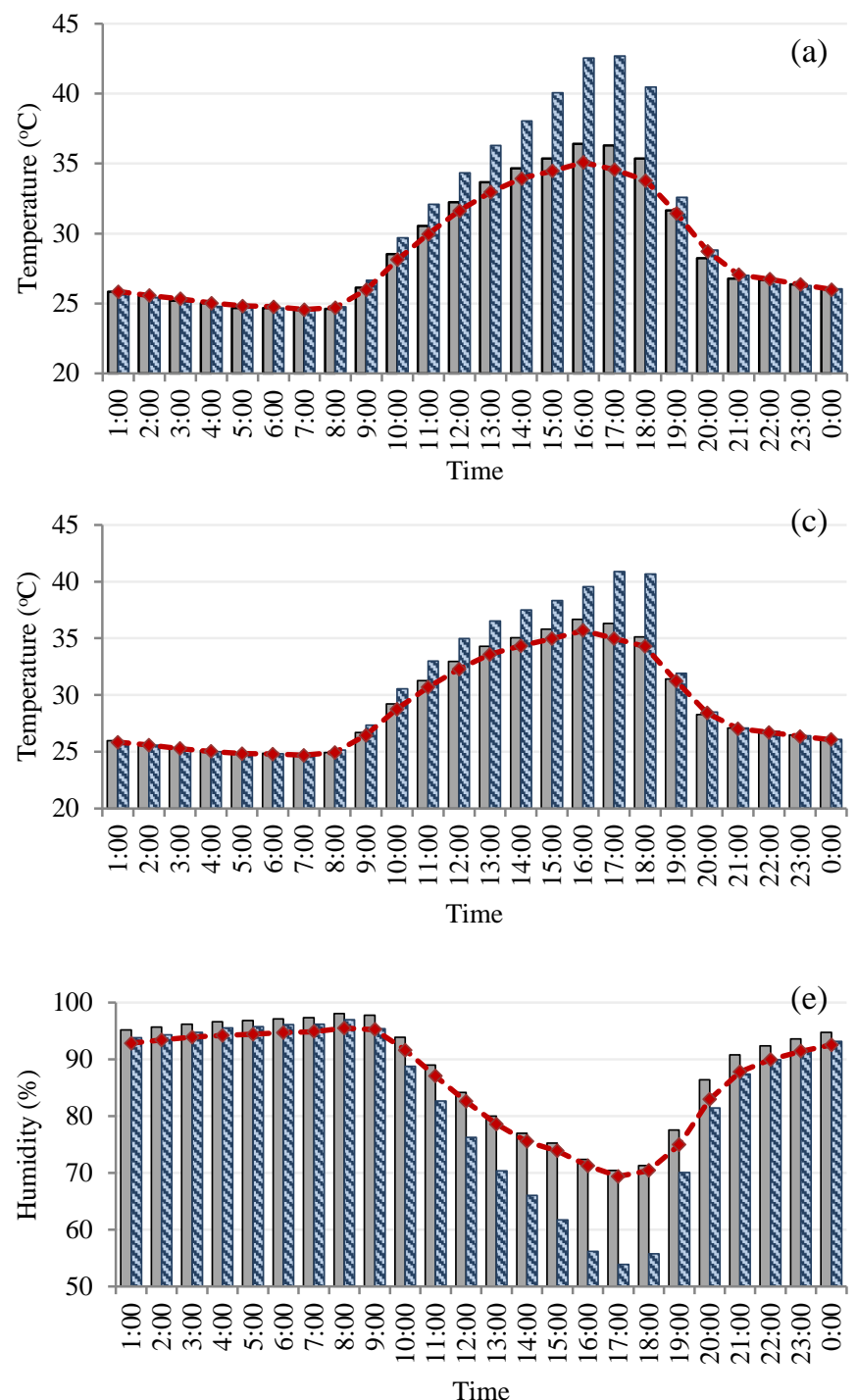

$--\bullet--$ Liwing wall


Green Facade

Benchmark

Fig. 4. Comparison between test boxes with living wall, green facade and benchmark for cavity air temperature (a), inside air temperature (b), cavity surface temperature (c), inside surface temperature (d), cavity humidity, and inside humidity (f).

\section{B. Effects of Ventilation on Vertical Greenery Systems}

Air movement and ventilation are necessary to achieve thermal comfort. Natural ventilation is an important and readily available kind of ventilation. Openings have a significant role in creating and controlling natural ventilation. The first part of the current experiment was completed when all openings in the test box were closed. In the second part of the test, the openings were opened to examine the performance of the vertical greenery systems with natural ventilation. The openings were on the side opposite the vertical greenery systems, on the east walls, and they did not affect the vertical greenery systems. Data was collected from May 26, 2013 until June 19, 2013. Data from rainy and full cloudy days was excluded and only the averages from full sunny days were used. The average temperatures for a 24 hour period for the living wall and green facade were compared.
Fig. 5 shows the results of the thermal comparison between all three test boxes when natural ventilation was used. The results showed that during the night and morning, the three test boxes had approximately the same inside temperature, although the test box behind the green facade was $0.5^{\circ} \mathrm{C}$ warmer than the others. During the afternoon, both the green facade and living wall reduced inside temperatures effectively. The greatest temperature reduction for the living wall and green facade was $3.5^{\circ} \mathrm{C}$ and $2.5^{\circ} \mathrm{C}$, respectively.

The natural ventilation and living wall provided better thermal performance than the green facade and the efficiency of the living wall was better when there was no natural ventilation. Natural ventilation can balance indoor thermal condition, and it is necessary for greenery systems. It is essential to examine natural ventilation when openings and vertical greenery systems face the same direction and when openings are affected by vertical greenery systems. 


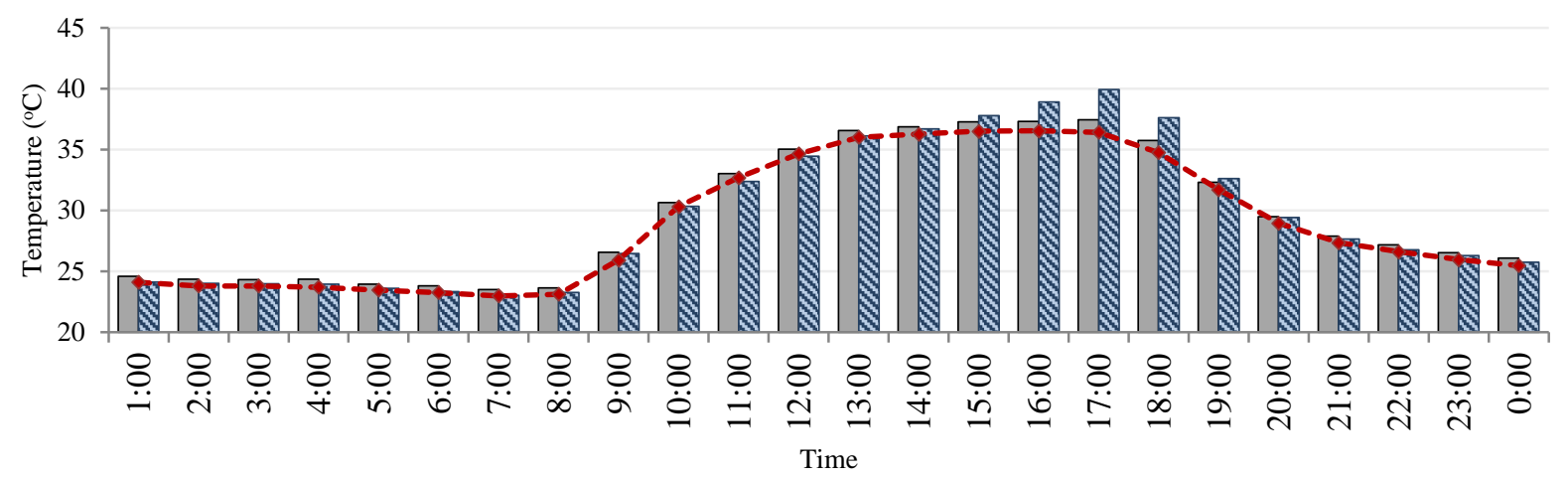

$\square$ Green Facade- Average Inside Temperature

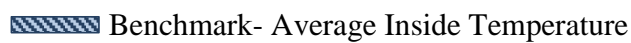

- - - Living Wall- Average Inside Temperature

Fig. 5. Indoor temperature comparison of the boxes behind living wall, green facade and the benchmark when natural ventilation was used.

\section{IV.CONCLUSION AND RECOMMENDATION}

This study was conducted to examine the thermal performance of green facades and living walls on the conditions found in the cavity between the vertical greenery systems and wall surfaces and the indoor temperatures in the hot and humid climate of Malaysia. The sizes, materials, plants species, and orientations were the same for both the green facade and living wall. Based on the results, living wall reduced temperatures better than the green facade. Table I compares the temperature for the living wall and green facade.

The living wall reduced the air temperature of the cavity up to $8.0^{\circ} \mathrm{C}$. Moreover, the living wall reduced indoor air temperature up to $4.0^{\circ} \mathrm{C}$. The direct connection between surface temperature and air temperature reveals that living wall reduces both inside and outside air and surface temperatures better than green facade.

TABLE I

TemPerature Reduction PROVIDED By the LIVING WALl AND GReEN FACADE

\begin{tabular}{|c|c|c|c|c|c|}
\cline { 2 - 6 } \multicolumn{1}{c|}{} & $\begin{array}{c}\text { Cavity } \\
\text { Air } \\
\text { Temp. }\end{array}$ & $\begin{array}{c}\text { Indoor } \\
\text { Air } \\
\text { Temp. }\end{array}$ & $\begin{array}{c}\text { Indoor Air } \\
\text { Temp. when } \\
\text { Ventilation } \\
\text { is Being }\end{array}$ & $\begin{array}{c}\text { Cavity } \\
\text { Surface } \\
\text { Temp. }\end{array}$ & $\begin{array}{c}\text { Indoor } \\
\text { Surface } \\
\text { Temp. }\end{array}$ \\
\hline $\begin{array}{c}\text { Living } \\
\text { wall }\end{array}$ & $8.0^{\circ} \mathrm{C}$ & $4.0^{\circ} \mathrm{C}$ & $3.5^{\circ} \mathrm{C}$ & $6.3{ }^{\circ} \mathrm{C}$ & $4.0^{\circ} \mathrm{C}$ \\
\hline $\begin{array}{c}\text { Green } \\
\text { Facade }\end{array}$ & $6.5{ }^{\circ} \mathrm{C}$ & $3.0^{\circ} \mathrm{C}$ & $2.5^{\circ} \mathrm{C}$ & $5.5^{\circ} \mathrm{C}$ & $3.5^{\circ} \mathrm{C}$ \\
\hline
\end{tabular}

The superior performance of the living wall in terms of temperature reduction is due to the material used to construct the living wall and the plants. Although a green facade is capable of allowing air to pass through the foliage and ventilating the air cavity, the shade provided by the living wall more effectively reduce temperatures. In future experiments, denser foliage for the green facade should be considered with different plants that can fill all areas on the trellis is recommended. Additionally, different substrate types should be investigated for living walls to compare their thermal performance and find the most efficient substrate for hot and humid climates.

The disadvantage of both vertical greenery systems examined in this study was that they increased humidity. The humidity of the green facade cavity was higher than living wall. The foliage in the cavity created higher humidity. The indoor humidity of the living wall was higher in comparison to the green facade because the humidity inside the test box could not be ventilated through the living wall. Providing openings and ventilation strategies are necessary to control indoor humidity when using a vertical greenery system. Natural ventilation can reduce the effect of vertical greenery system on temperatures, but it helps to have pleasant inside environment. The potential of vertical greenery systems with ventilation requires further study.

\section{ACKNOWLEDGMENT}

This research was supported by the Universiti Teknologi Malaysia (UTM). The authors would like to acknowledge the research funding by Universiti Teknologi Malaysia (UTM) and International Doctoral Fellowship (IDF).

\section{REFERENCES}

1. Wong, N. H., et al. Perception Studies of Vertical Greenery Systems in Singapore. Journal of Urban Planning and Development-Asce, 2010, vol. 136 , No. 4 , pp. 330-338. http://dx.doi.org/10.1061/(ASCE)UP.1943-5444.0000034

2. Yu, C., Hien, W. Thermal Impact of Strategic Landscaping in Cities: A Review. Advances in Building Energy Research (ABER), 2009, vol. 3, No. 1, 237 p. http://dx.doi.org/10.3763/aber.2009.0309

3. Cheng, C. Y., Cheung, K. K. S., Chu, L. M. Thermal performance of a vegetated cladding system on facade walls. Building and Environment, 2010, vol. 45, No. 8, pp. 1779-1787.

http://dx.doi.org/10.1016/j.buildenv.2010.02.005

4. Wong, N. H., et al. Thermal evaluation of vertical greenery systems for building walls. Building and Environment, 2010, vol. 45, No. 3, pp. 663-672. http://dx.doi.org/10.1016/j.buildenv.2009.08.005

5. Loh, S., Stav, Y. Green a city grow a wall. In: Proceedings of the Subtropical Cities 2008 Conference: From Fault-lines to Sight-lines: Subtropical Urbanism in 20-20, 2008.

6. Shiah, K., Kim, J. W., Oldridge, S. An Investigation into the Application of Vertical Garden at the New SUB Atrium. The University of British Columbia. 2011. 
7. Binabid, J. Vertical Garden: The study of vertical gardens and their benefits for low-rise buildings in moderate and hot climates. M. B. S. thesis. United States, California: University of Southern California, 2010. 126 p.

8. Jaafar, B., Said, I., Rasidi, M. H. Evaluating the Impact of Vertical Greenery System on Cooling Effect on High Rise Buildings and Surroundings: A Review. In: The 12th International Conference on Sustainable Environment and Architecture (Senvar) Indonesia, 2011.

9. Donahue, J. An empirical analysis of the relationships between tree cover, air quality, and crime in urban areas. M. P. P. thesis. United States, District of Columbia: Georgetown University, 2011. 123 p.

10. Amir, A., et al. The Most Effective Malaysian Legume Plants as Biofacade for Building Wall Application. Journal of Sustainable Development, 2011, vol. 4, No. 1, p. 103. http://dx.doi.org/10.5539/jsd.v4n1p103

11. Eumorfopoulou, E. A., Kontoleon, K. J. Experimental approach to the contribution of plant-covered walls to the thermal behaviour of building envelopes. Building and Environment, 2009, vol. 44, No. 5, pp. 1024-1038. http://dx.doi.org/10.1016/j.buildenv.2008.07.004

12. Picot, X. Thermal comfort in urban spaces: impact of vegetation growth: Case study: Piazza della Scienza, Milan, Italy. Energy and Buildings, 2004, vol. 36, No. 4, pp. 329-334 http://dx.doi.org/10.1016/j.enbuild.2004.01.044

13. White, E. V., Gatersleben, B. Greenery on residential buildings: Does it affect preferences and perceptions of beauty? Journal of Environmental Psychology, 2011, vol. 31, No. 1, pp. 89-98. http://dx.doi.org/10.1016/j.jenvp.2010.11.002

14. Perini, K., et al. Greening the building envelope, façade greening and living wall systems. Open Journal of Ecology, 2011, vol. 1, No 1, pp. 1-8. http://dx.doi.org/10.4236/oje.2011.11001

15. Kontoleon, K. J., Eumorfopoulou, E. A. The effect of the orientation and proportion of a plant-covered wall layer on the thermal performance of a building zone. Building and Environment, 2010, vol. 45, No. 5, pp. 1287-1303. http://dx.doi.org/10.1016/j.buildenv.2009.11.013

16. Price, J. Green facade energetics. M.S. thesis. United States, Maryland: University of Maryland, College Park, 2010, 105 p.

17. Wong, N. H., et al. Energy simulation of vertical greenery systems. Energy and Buildings, 2009, vol. 41, No. 12, pp. 1401-1408. http://dx.doi.org/10.1016/j.enbuild.2009.08.010

18. Perez, G., et al. Behaviour of green facades in Mediterranean Continental climate. Energy Conversion and Management, 2011, vol. 52, No. 4, pp. 1861-1867.

http://dx.doi.org/10.1016/j.enconman.2010.11.008

19. Sunakorn, P., Yimprayoon, C. Thermal Performance of Biofacade with Natural Ventilation in the Tropical Climate. Procedia Engineering, 2011, vol. 21, pp. 34-41. http://dx.doi.org/10.1016/j.proeng.2011.11.1984

20. Perini, K., et al. Vertical greening systems and the effect on air flow and temperature on the building envelope. Building and Environment, 2011, vol. 46, No. 11, pp. 2287-2294. http://dx.doi.org/10.1016/j.buildenv.2011.05.009

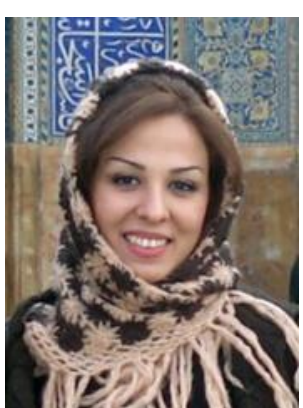

Tabassom Safikhani received her master from University of Art, Tehran, Iran, in 2009. She pursued her education as a $\mathrm{PhD}$ student of architecture in Universiti Teknologi Malaysia (UTM) from 2011. Her research field is greenery systems and vertical gardens. She was working as an architect in Espadana Consulting Engineers in Iran from 2004 until 2006.

E-mail: tabassomsafikhani@yahoo.com

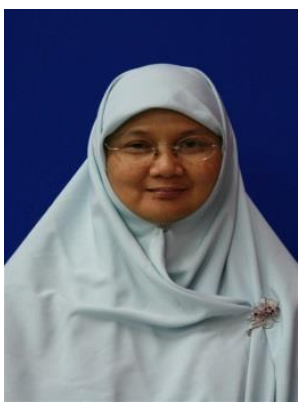

Aminatuzuhariah Megat Aminatuzuhariah received her master from University of Glamorgan, Wales, in 1996, and her $\mathrm{PhD}$ from University of Manchester, in 2000. She has taught at Universiti Teknologi Malaysia where she is Associate Professor. Her area of interest is sustainable building design. Her administrative position is head of department external programmers.

E-mail:min_abdullah@yahoo.co.uk

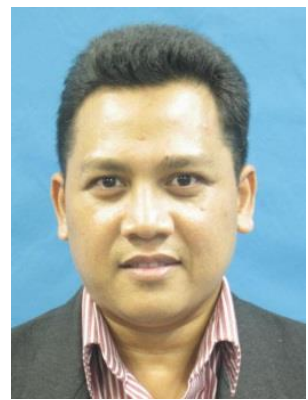

Dilshan Remaz Ossen received his master from University of Moratuwa, Colombo, Sri Lanka, in 1998, and his PhD from Universiti Teknologi Malaysia, in 2005. He has taught at Universiti Teknologi Malaysia where he is currently senior lecturer. His areas of interest are climatic consideration and passive design strategies in building, and urban design and conservation. E-mail: ardrossen@gmail.com

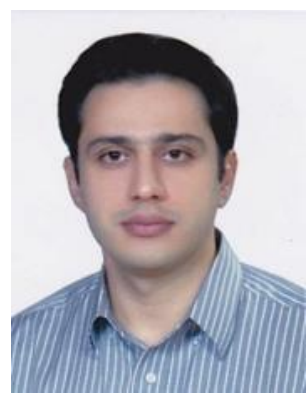

Mohammad Baharvand received his master from Azad University of Khorasgan-Esfahan-Iran in 2006. He pursued his education as a $\mathrm{PhD}$ student of architecture in Universiti Teknologi Malaysia from 2011.

He was working as an architect in Espadana Consulting Engineers in Iran from 2004 until 2011. His PhD research focuses on double skin facade and natural ventilation.

$\mathrm{He}$ is a research assistant and design officer at Institute Sultan Iskandar (ISI) and a member of Iranian Architecture society.

E-mail: baharvand12@gmail.com 